\title{
EXAMINING FACTORS AFFECTING CUSTOMERS' INTENTION TO USE E-BANKING IN VIETNAM
}

Vu Thi Kim Chi

Banking Academy of Vietnam

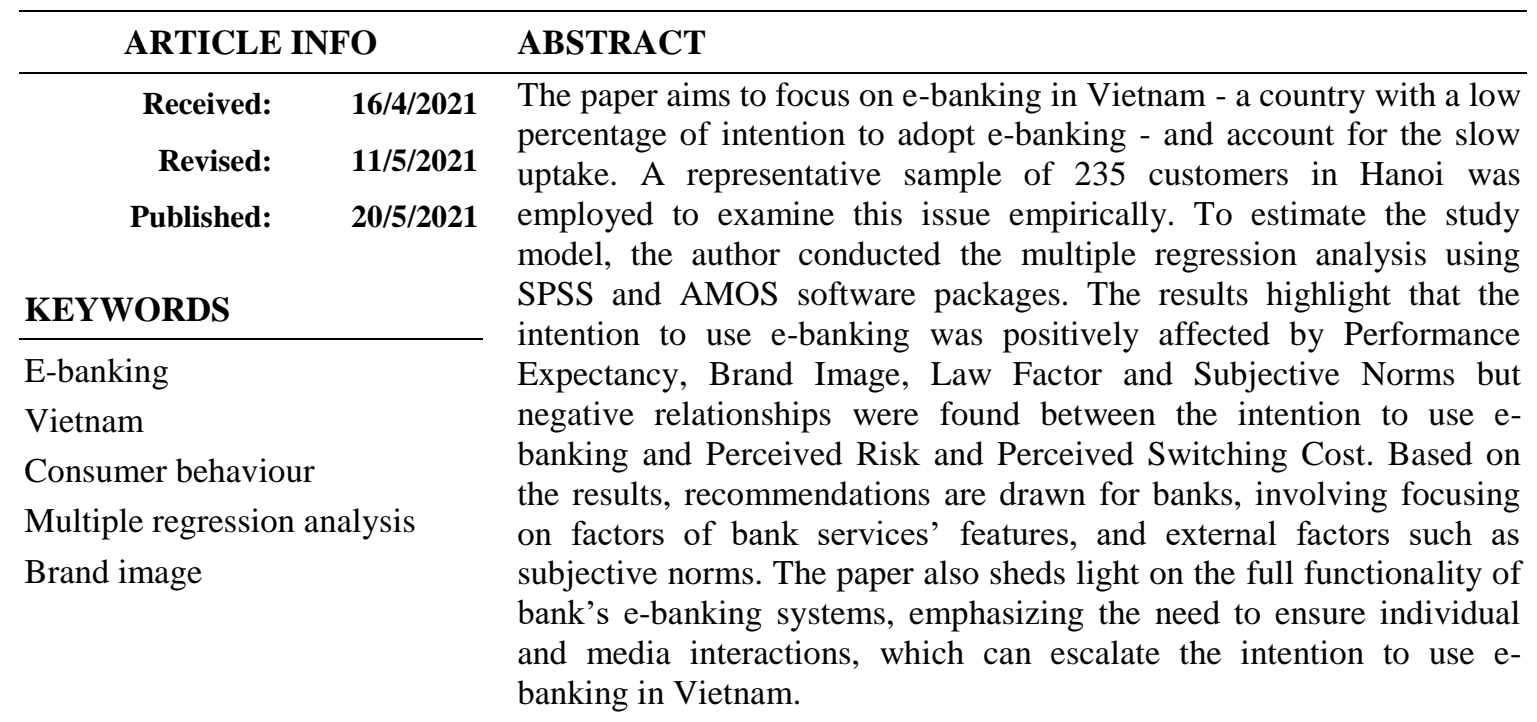

\section{PHÂN TÍCH CÁC NHÂN TỐ TÁC ĐộNG ĐẾN Ý ĐỊNH SỬ DỤNG E-BANKING CỦA KHÁCH HÀNG Ở VIỆTT NAM}

Vũ Thị Kim Chi

Học viện Ngân hàng

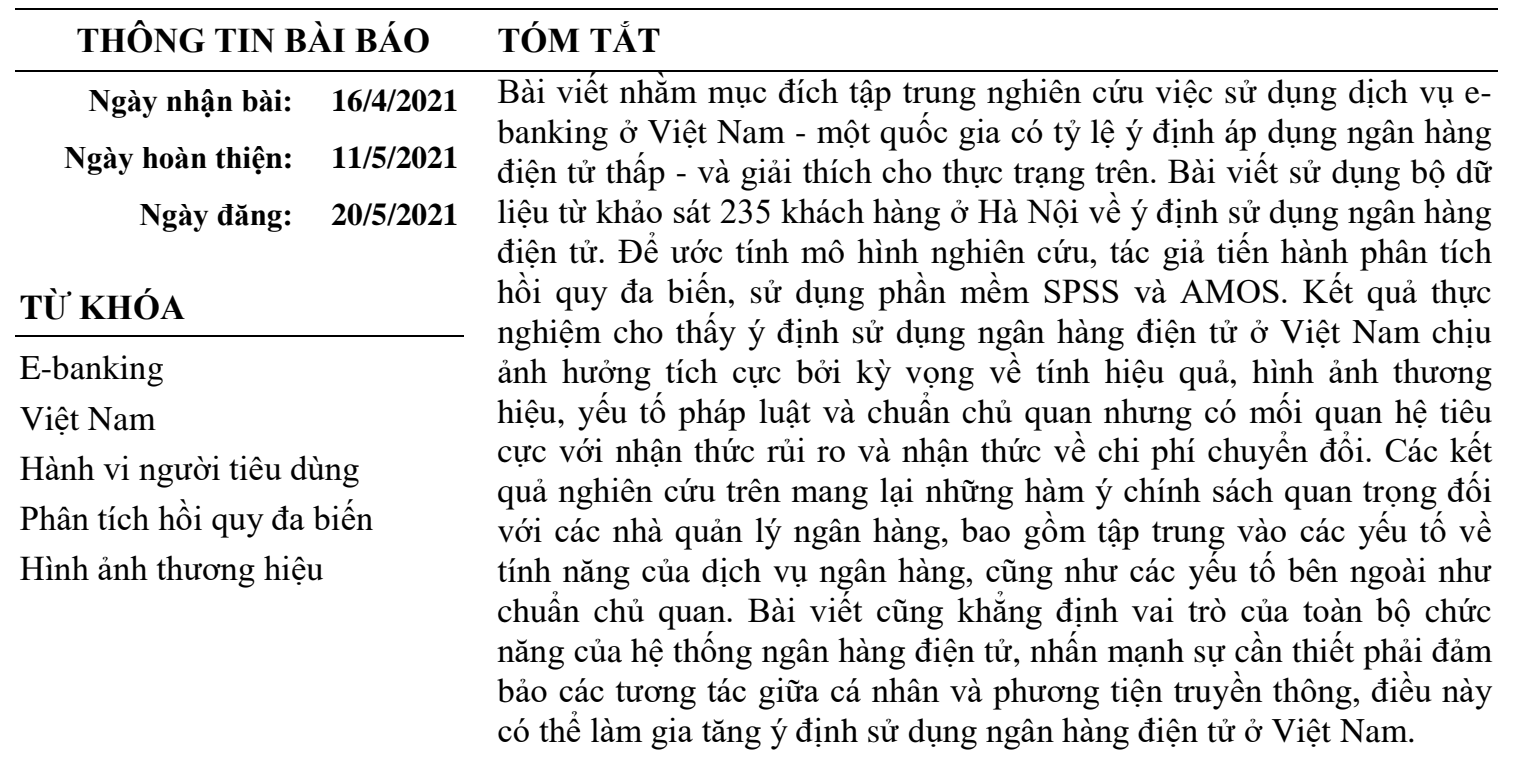

DOI: https://doi.org/10.34238/tnu-jst.4369

Email: chivtk@hvnh.edu.vn 


\section{Introduction}

In the context of an increasingly integrated and competitive world, banks have recognized the need to have more proper and up-to-date services to serve customers and distinguish themselves from other rivals, one of which is e-banking with its numerous advantages for both banks and consumers [1]. This concept can be understood as the employment of Internet-based banking services to help customers carry out banking transactions [1], [2]. E-banking also leads to the reduction of transaction costs of traditional banking services, such as the cost of paperwork, legal fees, communication charges, or hiring the labor required for performing financial services. Thus, e-banking has been embraced by many bank managers in light of the numerous benefits it confers on both improving banks' competitiveness and ensuring their effective interaction with customers [3].

Although these e-banking services are of great value to customers and resources have been put into integrating e-banking technology into banks' operations, many customers are not willing to use them [4], [5] and the percentage of customers adopting e-banking in many nations remains low [1], [6], [7]. Studies conducted by some researchers [8], [9] pointed out that banks in England and Turkey have not successfully attracted customers to accept Internet banking. In other less developed nations such as Jordan, there is a preference for traditional methods of conducting financial services rather than online banking [1]. However, Jordan is known as one of the pioneering adopters of Internet banking with a high level of investment in building Internet technology infrastructure in the Middle East [10]. Such a low rate of e-banking adoption can possibly create a number of problems for the banking sector [11] and therefore banks need to identify the different factors that influence the consumers' intention to adopt online banking [12], making the e-services more enticing, useful and user-friendly. From the customers' perspective, they need to be made aware of the important implications behind using e-banking services so that they can feel more secure and increase the propensity to adopt e-banking [13]. Hence, it has become crucial for bank managers to evaluate the factors that can either impede or encourage the acceptance and usage of e-banking, based on which they can formulate appropriate strategies to increase the rate of online banking adoption [5].

A number of previous studies have been conducted to justify the factors impacting consumers' intention to use e banking, which remains a popular topic of research. Despite this, extant online banking adoption literature focuses mainly on developed countries [12] and scant empirical research on this issue has been done in countries with low e-banking usage, which is a research gap in prior studies. Although the proportion of people using the Internet is accelerating in Vietnam, the figure for e-banking adopters is not impressive. In filling this gap in the Internet banking literature, this study investigates the different factors that influence the intention to use e-banking at the country level. The study results are expected to be of great value for both practitioners and academia in the banking sector. Therefore, this study proposes a research model based on the Technology Acceptance Model (TAM) to examine the main factors that influence the decision to use e-banking in Vietnam. This model employs not only the common positive predictors of technology adoption, such as perceived ease of use, subjective norms and brand image, but also negative variables, such as perceived risk, perceived switching costs.

The remaining sections are organized as follows. The second part discusses the research method used in this study, followed by the data analysis and discussion in the third section. Finally, the fourth section outlines the main conclusions and the potential steps for further research and the main limitations.

\section{Research methods}

The research method in this paper was based on the deductive approach. Primarily, this paper sought to identify the links between the influential factors and people's intention to use e- 
banking, especially from the respondents in Hanoi, Vietnam. Therefore, the research was conducted using the quantitative method of both paper-based and online questionnaire surveys.

\subsection{Sample and collection procedures}

The author randomly distributed the questionnaires to customers currently using banking services. In this manner, the randomness of the sample selection could be ensured to the maximum extent. The questionnaire also indicates that the information provided by the respondents would be kept in strict confidentiality and participation was voluntary to attempt. A pilot test was undertaken on a sample of 22 Vietnamese customers to ensure that the questionnaire is clear and comprehensible in terms of language and terminologies. The data was collected within the 60-day period from January with a convenience sampling method. Although this method has its limitations such as possibility of bias, the advantage is that habits, opinions, and viewpoints of the respondents can be observed in the easiest possible manner. The sample comprises of bank customers based in Hanoi city, Vietnam. A total of 250 questionnaires were filled; however, 15 were removed due to missing data. The 235 valid sampling units include $53.2 \%$ females and $46.8 \%$ males.

\subsection{Framework and Hypotheses development}

Based on the Theory of Reasoned Action [14] and the Technology Acceptance Model (TAM) [15], the author proposed the research model as illustrated in Figure 1.

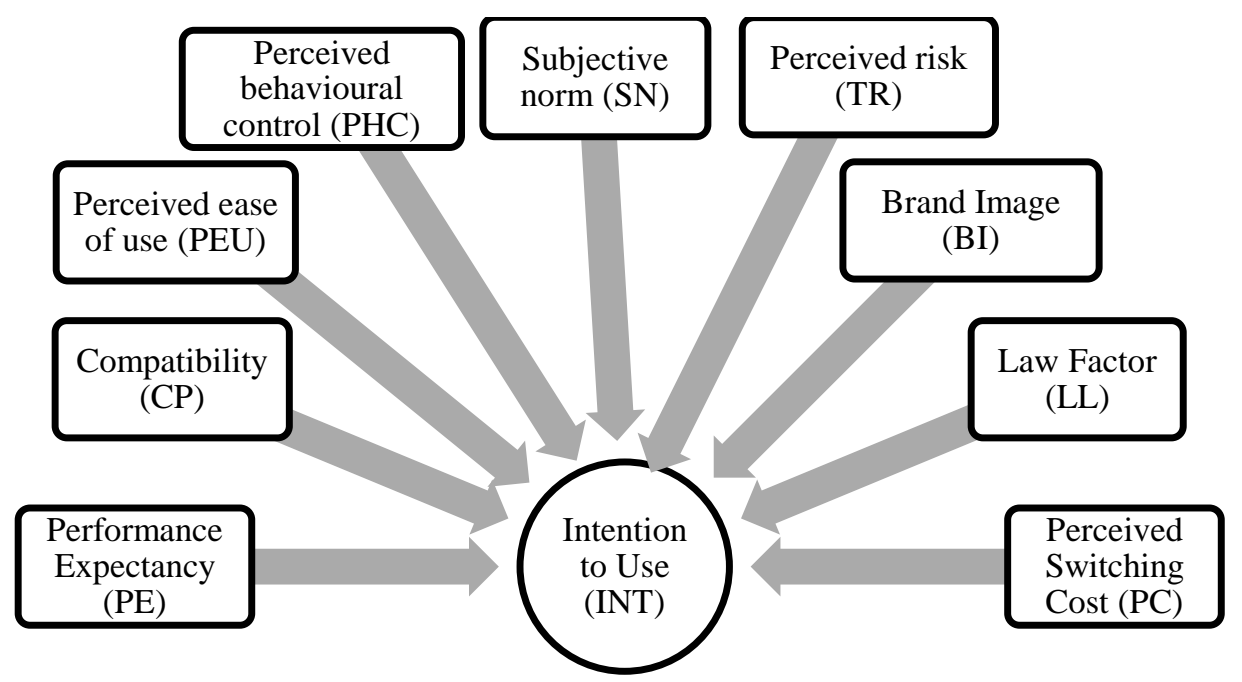

Figure 1. Proposed research model

\section{Performance expectancy and intention to use e-banking}

Performance expectancy means the consumers realize gains from the use of online banking, implying that the value customers derive from e-banking services can be greater than those available from brick-and-mortar based services. Using E-banking helps customers save time and costs for customers, thereby achieving greater efficiency in payment-related jobs as well as online transactions [1], [16], [17]. Based on that, the first hypothesis is formed as follows:

H1: Performance expectancy has a positive statistical impact on customers' intention to use ebanking.

\section{Compatibility and intention to use e-banking}

Compatibility refers to how well the service fits they way customers manage their financial situations and their lifestyles. If the customer perceives e-banking services more 
compatible to them, they will have a tendency to accept such services [18]. Thus, the following hypothesis is formulated:

H2: Compatibility has a positive statistical impact on customers' intention to use e-banking.

Perceived ease of use and intention to use e-banking

Perceived ease of use is a crucial determinant of system use in an organization, especially in adopting e-banking service [14], [19]. When customers feel the ease of use, they will feel the use is more advantageous and beneficial to use. This can be hypothesized as:

H3: Perceived ease of use has a positive impact on customers' intention to use e-banking.

\section{Perceived behavioural control and intention to use e-banking}

Perceived behavioural control is the customer's perception of e-banking service or the difficulties when performing e-banking transactions such as whether the customer have full resources when using the service or can fully control transactions by e-banking services. The better perceived behavioural control the customers have, the higher the level of customer ebanking service acceptance is [19]. Thus, the following hypothesis is formulated:

H4: Perceived behavioural control has a positive impact on customers' intention to use e-banking.

\section{Subjective norms and intention to use e-banking}

Subjective norms are interpreted as the consumer's social pressure to engage in e-banking transactions. One's perception of pressures from people who may be acquaintances or important people can affect the intention to adopt e-banking [20]. In this regard, the hypothesis can be proposed as below:

H5: Subjective norm has a positive impact on customers' intention to use e-banking.

\section{Perceived risk and intention to use e-banking}

Risks in online transactions are the risks that customers perceive when using the e-banking system, affecting customers' confidence in using this service. The choice of technology application is inversely proportional to the level of perceived risk. Defined risks are the objective damages that customers face when they cannot foresee the consequences of their use. The higher the customer's perception of this risk, the lower the level of acceptance to use e-banking service will be [21] - [25]. Based on the argument, the following hypothesis is proposed:

H6: Perceived risk has a negative impact on customers' intention to use e-banking.

\section{Brand image and intention to use e-banking}

Customers' perception of the brand's reputation, resources, and commitment policies as well as service support guidance of the bank has a positive impact on the customers' acceptance and use of e-banking. If they feel the banks have good brand image, they will have a higher level of e-banking acceptance [26], [27]. In this regard, the hypothesis can be proposed as below:

H7: Brand Image has a positive impact on customers' intention to use e-banking.

\section{Law factor and intention to use e-banking}

Law factor is the degree of influence of legal factors affecting the acceptance and use of EBanking. Like the government's laws on electronic transactions, the central banks' regulations on electronic transactions as well as the financial and monetary stability policy are put in place to protect interests and benefits of customers when using e-banking services [28], [29]. The clearer and more specific the policies and regulations are, the higher the level of e-banking adoption is.

H8: Law factor has a positive impact on customers' intention to use e-banking.

\section{Perceived switching cost and intention to use e-banking}

Perceived switching cost is defined as the extent to which a person believes that using a banking service will cost money. Costs may include the cost of bank fees or charges such as service fees, fees for performing transactions in the form of banking fees, network fees for sending information. This shows that the intention to adopt new technology is related to a reasonable switching cost, meaning that a lower switching cost can attract customers to use such e-banking service [26], [27]. Hence, the following hypothesis can be proposed:

H9: Perceived switching cost has a negative impact on customers' intention to use e-banking. 


\subsection{Variable measurements}

On the basis of the research objectives, a structured questionnaire was carefully designed with two sections. To be specific, the first section, which consists of six multiple-choice questions, aims at collecting demographic data of the sample. The second section, which is the main part of the questionnaire, seeks to examine how the significant factors affect the intention to use ebanking, in accordance with the research model constructed.

Five-point Likert Scale questions in this section essentially required the respondents to select to what extent they agreed with each item, ranging from "strongly disagree" to "strongly agree". Particularly, 36 items for all questions were cautiously adapted from prior studies. There are nine variables, namely Performance Expectancy (PE) [16], [17], Compatibility (CP) [18], Perceived ease of use (PEU) [14], [19], Perceived behavioural control (PHC) [19], Subjective norms (SN) [20], Perceived risk (TR) [19], Brand Image (BI) [30], Law Factor (LL) [28], Perceived Switching Cost (PC) [26], [27] and Intention to Use (INT) [14], [20], [26], [27].

Software tools named SPSS and AMOS were used to test the hypothetical model of the effect of Performance Expectancy, Compatibility, Perceived ease of use, Perceived behavioural control, Subjective norms, Perceived risk, Brand image, Perceived Switching cost and Law Factor on Intention to Use E-banking in Vietnam. Before conducting the multiple regression analysis, the author has conducted Cronbach's Alpha test and exploratory factor analysis (EFA) to measure the internal consistency and overall validity of the instrument. Linear regression was used in order to examine the significance and nature of the relationship between variables.

\section{Results and Discussion}

\subsection{Cronbach's Alpha results}

Table 1. Cronbach's Alpha test

\begin{tabular}{|c|c|c|}
\hline & Corrected Item-Total Correlation & Cronbach's Alpha if Item Deleted \\
\hline \multicolumn{3}{|c|}{ Performance Expectance (PE): Cronbach's Alpha $=0.858$} \\
\hline PE1 & 0.747 & 0.801 \\
\hline PE2 & 0.715 & 0.815 \\
\hline PE3 & 0.64 & 0.845 \\
\hline PE4 & 0.715 & 0.815 \\
\hline \multicolumn{3}{|c|}{ Compatibility $(P C):$ Cronbach’s Alpha $=0.898$} \\
\hline PC1 & 0.803 & 0.851 \\
\hline $\mathrm{PC} 2$ & 0.828 & 0.828 \\
\hline PC3 & 0.765 & 0.882 \\
\hline \multicolumn{3}{|c|}{ Perceived Ease of Use (PEU): Cronbach's Alpha $=0.837$} \\
\hline PEU1 & 0.645 & 0.803 \\
\hline PEU2 & 0.75 & 0.774 \\
\hline PEU3 & 0.642 & 0.804 \\
\hline PEU4 & 0.695 & 0.788 \\
\hline PEU5 & 0.474 & 0.847 \\
\hline \multicolumn{3}{|c|}{ Perceived Behavioural control (PHC): Cronbach's Alpha $=0.778$} \\
\hline PHC1 & 0.554 & 0.764 \\
\hline $\mathrm{PHC} 2$ & 0.698 & 0.603 \\
\hline PHC3 & 0.6 & 0.716 \\
\hline \multicolumn{3}{|c|}{ Subjective norm (SN): Cronbach's Alpha $=0.888$} \\
\hline SN1 & 0.79 & 0.835 \\
\hline SN2 & 0.781 & 0.842 \\
\hline SN3 & 0.775 & 0.847 \\
\hline
\end{tabular}




\begin{tabular}{lcc}
\hline & & \\
\hline & Corrected Item-Total Correlation & Cronbach's Alpha if Item Deleted \\
TR1 & Perceived risk (TR): Cronbach's Alpha $=0.896$ \\
TR2 & 0.789 & 0.858 \\
TR3 & 0.808 & 0.839 \\
\hline & 0.789 & 0.856 \\
BI1 & Brand Image (BI): Cronbach's Alpha $=0.886$ \\
BI2 & 0.627 & 0.874 \\
BI3 & 0.684 & 0.866 \\
BI4 & 0.668 & 0.868 \\
BI5 & 0.749 & 0.854 \\
BI6 & 0.689 & 0.865 \\
& 0.752 & 0.854 \\
LL1 & Law Factor (LL): Cronbach's Alpha $=0.884$ \\
LL2 & 0.818 & 0.796 \\
LL3 & 0.756 & 0.853 \\
& 0.761 & 0.852 \\
PC1 & Perceived Switching Cost (PC): Cronbach's Alpha $=0.913$ \\
PC2 & 0.8 & 0.897 \\
PC3 & 0.881 & 0.835 \\
\hline & 0.811 & 0.896 \\
INT1 & Intention to Use (INT): Cronbach's Alpha = 0.874 \\
INT2 & 0.748 & 0.83 \\
& 0.842 & 0.744 \\
INT3 & 0.703 & 0.871 \\
\hline
\end{tabular}

The Cronbach's Alphas of the nine constructs are displayed in Table 1. All Alphas are above the threshold of 0.70 [31], meaning that the reliability is confirmed.

\subsection{EFA results}

Table 2. Exploratory Factor Analysis (EFA) results

\begin{tabular}{|c|c|c|c|c|c|c|c|}
\hline \multirow{2}{*}{ Variable } & & \multicolumn{6}{|c|}{ Component } \\
\hline & & 1 & 2 & 3 & 4 & 5 & 6 \\
\hline \multirow{6}{*}{ Brand Image (BI) } & BI5 & 0.833 & & & & & \\
\hline & BI6 & 0.81 & & & & & \\
\hline & BI4 & 0.807 & & & & & \\
\hline & $\mathrm{BI} 3$ & 0.742 & & & & & \\
\hline & $\mathrm{BI} 2$ & 0.678 & & & & & \\
\hline & BI1 & 0.62 & & & & & \\
\hline \multirow{4}{*}{$\begin{array}{c}\text { Performance Expectancy } \\
\text { (PE) }\end{array}$} & PE1 & & 0.802 & & & & \\
\hline & PE4 & & 0.775 & & & & \\
\hline & PE2 & & 0.772 & & & & \\
\hline & PE3 & & 0.731 & & & & \\
\hline \multirow{3}{*}{ Perceived Risk (TR) } & TR2 & & & 0.902 & & & \\
\hline & TR3 & & & 0.861 & & & \\
\hline & TR1 & & & 0.855 & & & \\
\hline \multirow{3}{*}{$\begin{array}{c}\text { Perceived Switching Cost } \\
\text { (PC) }\end{array}$} & PC1 & & & & 0.926 & & \\
\hline & $\mathrm{PC} 2$ & & & & 0.883 & & \\
\hline & PC3 & & & & 0.815 & & \\
\hline \multirow{3}{*}{ Law Factor (LL) } & LL1 & & & & & 0.871 & \\
\hline & LL3 & & & & & 0.861 & \\
\hline & LL2 & & & & & 0.769 & \\
\hline
\end{tabular}




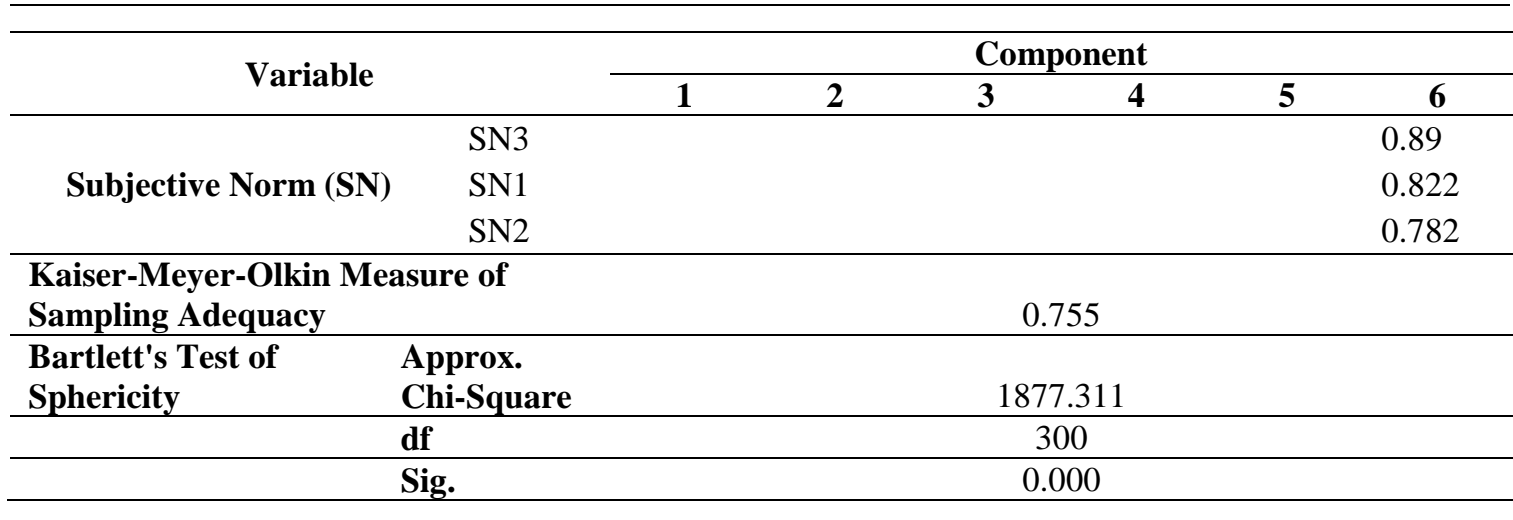

Table 3. Total Variance Explained

\begin{tabular}{|c|c|c|c|c|c|c|}
\hline \multirow{2}{*}{ Component } & \multicolumn{3}{|c|}{ Initial Eigenvalues } & \multicolumn{3}{|c|}{ Extraction Sums of Squared Loadings } \\
\hline & Total & \% of Variance & Cumulative \% & Total & \% of Variance & Cumulative \% \\
\hline 1 & 7.807 & 31.230 & 31.230 & 7.807 & 31.230 & 31.230 \\
\hline 2 & 3.730 & 14.922 & 46.151 & 3.730 & 14.922 & 46.151 \\
\hline 3 & 2.585 & 10.339 & 56.490 & 2.585 & 10.339 & 56.490 \\
\hline 4 & 1.999 & 7.995 & 64.486 & 1.999 & 7.995 & 64.486 \\
\hline 5 & 1.478 & 5.911 & 70.397 & 1.478 & 5.911 & 70.397 \\
\hline 6 & 1.206 & 4.825 & 75.222 & 1.206 & 4.825 & 75.222 \\
\hline 7 & 1.059 & 4.236 & 79.458 & & & \\
\hline 8 & 0.750 & 3.001 & 82.459 & & & \\
\hline 9 & 0.672 & 2.689 & 85.148 & & & \\
\hline 10 & 0.518 & 2.073 & 87.221 & & & \\
\hline 11 & 0.440 & 1.758 & 88.979 & & & \\
\hline 12 & 0.413 & 1.650 & 90.630 & & & \\
\hline 13 & 0.354 & 1.416 & 92.045 & & & \\
\hline 14 & 0.312 & 1.246 & 93.292 & & & \\
\hline 15 & 0.292 & 1.167 & 94.459 & & & \\
\hline 16 & 0.245 & 0.980 & 95.439 & & & \\
\hline 17 & 0.210 & 0.840 & 96.279 & & & \\
\hline 18 & 0.186 & 0.745 & 97.024 & & & \\
\hline 19 & 0.168 & 0.673 & 97.697 & & & \\
\hline 20 & 0.146 & 0.584 & 98.281 & & & \\
\hline 21 & 0.122 & 0.487 & 98.767 & & & \\
\hline 22 & 0.099 & 0.397 & 99.165 & & & \\
\hline 23 & 0.078 & 0.313 & 99.478 & & & \\
\hline 24 & 0.071 & 0.283 & 99.761 & & & \\
\hline 25 & 0.060 & 0.239 & 100.000 & & & \\
\hline
\end{tabular}

Extraction Method: Principal Component Analysis.

EFA results show that the statistical indicators are suitable (Table 2). The Exploratory factor analysis (with the extraction method of Principal Component Analysis and the rotation method of Varimax) was conducted on a pool of the 33 items to identify the factors affecting the intention to use e-banking. In the final solution, $\mathrm{KMO}=0.755>0.5$, so it satisfies requirements of factor analysis $\left.(0.5 \leq \mathrm{KMO} \leq 1) \chi^{2}(\mathrm{df}=300)=1877.311 ; \mathrm{p}<0.001\right), 22$ out of the original 33 items were retained, resulting in six factors which accounted for $75.222 \%$ of variance in the data (Table 3). Six independent variables that can influence the intention to use e-banking (INT) are Performance Expectancy (PE), Subjective norms (SN), Perceived Risk (TR), Brand Image (BI), Law Factor (LL), Perceived Switching Cost (PC). 


\subsection{Results of estimating the model}

In order to investigate the proposed hypotheses, a regression analysis was conducted in line with the statistics from the questionnaire survey. Table 4 provides the results of the regression analysis. The Adjusted R Square value is 0.408 , which means that the six independent variables can explain $40.8 \%$ of the variability in the customers' intentions to use e-banking.

Table 4. Model Summary

\begin{tabular}{cccccc}
\hline Model & R & R Square & $\begin{array}{c}\text { Adjusted R } \\
\text { Square }\end{array}$ & $\begin{array}{c}\text { Std. Error of the } \\
\text { Estimate }\end{array}$ & Durbin-Watson \\
\hline 1 & $0.667^{\mathrm{a}}$ & 0.445 & 0.408 & 0.67897 & 0.1812 \\
\hline
\end{tabular}

To ensure certain validity and reliability of the model and the regression coefficients in the model equation, F-test and t-test were undertaken based on the results presented in the Table 5 and Table 6. Firstly, as seen from Table 5, F $=12.034$ and the Sig. $=0.000 \leq 0.05$, which indicates that the model is significant. The results in Table 6 , which provide the $t$ values of all the independent variables, suggest that all six independent variables are significant as their Sig. values are all lower than 0.05 .

Table 5. ANNOVA

\begin{tabular}{|c|c|c|c|c|c|}
\hline Model & Sum of Squares & df & Mean Square & $\mathbf{F}$ & Sig. \\
\hline 1 Regression & 33.285 & 6 & 5.547 & 12.034 & $0.000^{\mathrm{b}}$ \\
\hline Residual & 41.490 & 90 & 0.461 & & \\
\hline Total & 74.774 & 96 & & & \\
\hline $\begin{array}{l}\text { a. Dependent } \\
\text { b. Predictors: }(C\end{array}$ & $\begin{array}{l}\mathrm{NT} \\
\mathrm{N}, \mathrm{PC}, \mathrm{LL}, \mathrm{PE}, \mathrm{B}\end{array}$ & & & & \\
\hline
\end{tabular}

Table 6. Coefficient

\begin{tabular}{|c|c|c|c|c|c|c|c|c|}
\hline & \multirow{2}{*}{ Model } & \multicolumn{2}{|c|}{$\begin{array}{c}\text { Unstandardized } \\
\text { Coefficients }\end{array}$} & \multirow{2}{*}{$\begin{array}{c}\begin{array}{c}\text { Standardized } \\
\text { Coefficients }\end{array} \\
\text { Beta }\end{array}$} & \multirow[t]{2}{*}{$\mathbf{t}$} & \multirow{2}{*}{ Sig. } & \multicolumn{2}{|c|}{ Collinearity Statistics } \\
\hline & & B & Std. Error & & & & Tolerance & VIF \\
\hline \multirow[t]{7}{*}{1} & (Constant) & 1.473 & 0.604 & & 2.439 & 0.017 & & \\
\hline & $\mathrm{PE}$ & 0.452 & 0.111 & 0.388 & 4.085 & 0.000 & 0.683 & 1.463 \\
\hline & $\mathrm{BI}$ & 0.006 & 0.129 & 0.004 & 0.045 & 0.004 & 0.650 & 1.539 \\
\hline & TR & -0.083 & 0.100 & -0.075 & -0.834 & 0.006 & 0.759 & 1.318 \\
\hline & $\mathrm{PC}$ & -0.183 & 0.078 & -0.215 & -2.341 & 0.021 & 0.729 & 1.372 \\
\hline & LL & 0.108 & 0.122 & 0.084 & 0.886 & 0.008 & 0.681 & 1.468 \\
\hline & SN & 0.231 & 0.093 & 0.236 & 2.483 & 0.015 & 0.681 & 1.468 \\
\hline
\end{tabular}

Dependable variable: INT

Based on this basis, the results of estimating the study model have the following equation:

$\mathrm{INT}=0,388 * \mathrm{PE}+0.004 * \mathrm{BI}-0.075 * \mathrm{TR}-0.025 * \mathrm{PC}+0.084 * \mathrm{LL}+0.236 * \mathrm{SN}+\varepsilon$

Impact of performance expectancy (PE) on intention to use e-banking (INT): The results show that performance expectancy (PE) has a positive impact on the intention to use e-banking. This result is consistent with the previous studies [27], [32], [33], which confirmed that performance expectancy is identified as a significant antecedent of Internet banking acceptance.

Impact of perceived risk (TR) on intention to use e-banking (INT): The results indicate that perceived risk is an important factor that negatively affects customers' intention to use ebanking. This is in line with results from other researches [21] - [25]. This finding offers insights for bank managers to motivate customers to develop greater risk acceptance and minimize the negative impact of the perceived risk of the adoption of e-banking. Some of the possible strategies to foster a high level of confidence in customers that bank management should consider include implementing safeguarding measure of intrusion and identity theft, 
using security devices to protect internet banking security systems or building service recovery programs for customers' transactions.

Impact of Brand image (BI) on intention to use e-banking (INT): A positive relationship has been found between the image of the bank and customers' intention to use e-banking. This impact is consistent with findings from prior studies [21]. The implication is that banks should develop a marketing communication that to enhance brand image, or bank image, in the online context. An image of high quality and reliability related to banks' services, especially online ones, should be created in the mind of consumers to encourage the adoption rate of e-banking.

Impact of perceived switching cost (PC) on intention to use e-banking (INT): The results indicate that perceived switching cost negatively affects customers' intention to use e-banking. This is consistent with the finding by [26], [34] who labeled perceive switching cost as the factor determining consumer adoption of Internet banking. Since the impact of perceived switching cost on intention to use e-banking is quite significant, it is advisable for bank managers to reconsider price policies in order to increase the acceptance of e-banking.

Impact of law (LL) on intention to use e-banking (INT): The results indicate that law factor positively impacts customers' intention to use e-banking [28], [29]. The government plays an important role in improving the acceptance of e-banking services among customers their by designing policies to foster the use of this channel, such as Internet security policies and consumer protection legislation. The customers will be more likely to use e banking since they feel more secure and comfortable with internet technology. The Vietnamese government has spent decades concentrating on developing the digital sector, and the empirical results confirm a reasonable level of effectiveness with regard to the implementation of e-banking services.

Impact of subjective norms (SN) on intention to use e-banking (INT): The results indicate that subjective norms are statistically significant in directly affecting the intention to use e-banking. This resonates with the research results by [35], [36]. Vietnamese people tend to be sensitive to other people's opinions and expectations. Thus, bank managers should focus on personal referents to encourage e-banking adoption among bank customers and deploy social media as a channel of communication in an effort to increase the rate of e-banking adoption.

\section{Conclusion}

In this study, a number of factors that contribute to encouraging the intention to use e-banking amongst Vietnamese customers are illustrated in the banking industry, using TAM model. With the deployment of multiple regression analysis, the study has found that the intention to use ebanking is positively affected by performance expectancy, brand image, law factor, and subjective norms. However, perceived switching costs and perceived risk are notable as barriers to intention to use e-banking services, negatively impacting the customers' propensity to use ebanking services. These are important policy implications for the managers at the banks. In order to improve customers' intention to adopt e-banking, bank managers need to formulate effective strategies for delivery channels to retain and broaden the current network of customers. Another important implication is that bank managers can take advantage of marketing communications to widely publicize the benefits associated with the use of e-banking to wider consumers. Bankers can apply advertising techniques to impact consumers' attitudes toward e-banking services, which, in turn, can lead to a higher likelihood of using e-banking. Despite the contributions, the research has some limitations. One of the biggest constraints is the sample size, with only 235 respondents. A larger sample would yield more significant results. Additionally, the study was conducted on a country level, making a cross comparison between countries difficult. Therefore, future researches should be conducted on a larger scale, incorporating both developed and developing nations. 


\section{REFERENCES}

[1] A. Anouze and A. Alamro, "Factors affecting intention to use e-banking in Jordan," International Journal of Bank Marketing, vol. 38, no. 1, pp. 86-112, 2019, doi: 10.1108/ijbm-10-2018-0271.

[2] M. Sathye, "Adoption of Internet banking by Australian consumers: an empirical investigation," International Journal of Bank Marketing, vol. 17, no. 7, pp. 324-334, 1999, doi: $10.1108 / 02652329910305689$.

[3] O. Stoica, S. Mehdian and A. Sargu, "The Impact of Internet Banking on the Performance of Romanian Banks: DEA and PCA Approach," Procedia Economics and Finance, vol. 20, pp. 610-622, 2015, doi: 10.1016/s2212-5671(15)00115-x.

[4] W. Chaouali, I. Ben Yahia and N. Souiden, "The interplay of counter-conformity motivation, social influence, and trust in customers' intention to adopt Internet banking services: The case of an emerging country," Journal of Retailing and Consumer Services, vol. 28, pp. 209-218, 2016, doi: 10.1016/j.jretconser.2015.10.007.

[5] A. Tarhini, M. El-Masri, M. Ali and A. Serrano, "Extending the UTAUT model to understand the customers' acceptance and use of internet banking in Lebanon," Information Technology \& People, vol. 29, no. 4, pp. 830-849, 2016, doi: 10.1108/itp-02-2014-0034.

[6] A. Shaikh and H. Karjaluoto, "Mobile banking adoption: A literature review," Telematics and Informatics, vol. 32, no. 1, pp. 129-142, 2015, doi: 10.1016/j.tele.2014.05.003.

[7] K. Shih, H. Hung and B. Lin, "Assessing user experiences and usage intentions of m-banking service," International Journal of Mobile Communications, vol. 8, no. 3, p. 257 - 277, 2010, doi: 10.1504/IJMC.2010.032974.

[8] H. Çelik, "What determines Turkish customers' acceptance of internet banking?" International Journal of Bank Marketing, vol. 26, no. 5, pp. 353-370, 2008, doi: 10.1108/02652320810894406.

[9] S. Yousafzai and M. Yani-de-Soriano, "Understanding customer-specific factors underpinning internet banking adoption," International Journal of Bank Marketing, vol. 30, no. 1, pp. 60-81, 2012, doi: 10.1108/02652321211195703.

[10] M. AL-Majali, and N. K. N. Mat, "Modeling the antecedents of internet banking service adoption (IBSA) in Jordan: A Structural Equation Modeling (SEM) approach," Journal of Internet Banking and Commerce, vol. 16, no. 1, pp. 1-15, 2011.

[11] A. Alalwan, Y. Dwivedi, and M. Williams, "Examining factors affecting customer intention and adoption of internet banking in Jordan," UK Academy for Information Systems Conference Proceedings, Paper 3, Oxford, April 7-9, 2014.

[12] A. Montazemi and H. Qahri-Saremi, "Factors affecting adoption of online banking: A meta-analytic structural equation modeling study," Information \& Management, vol. 52, no. 2, pp. 210-226, 2015, doi: 10.1016/j.im.2014.11.002.

[13] F. Liébana-Cabanillas, V. Marinković, and Z. Kalinić, "A SEM-neural network approach for predicting antecedents of m-commerce acceptance," International Journal of Information Management, vol. 37, no. 2, pp. 14-24, 2017, doi: 10.1016/j.ijinfomgt.2016.10.008.

[14] F. Davis, R. Bagozzi and P. Warshaw, "User Acceptance of Computer Technology: A Comparison of Two Theoretical Models," Management Science, vol. 35, no. 8, pp. 982-1003, 1989, doi: 10.1287/mnsc.35.8.982.

[15] I. Ajzen and M. Fishbein, Understanding attitudes and predicting social behavior. Englewood Cliffs, N.J.: Prentice-Hall, 1980.

[16] K. Al-Qeisi, C. Dennis, A. Hegazy, and M. Abbad, "How Viable Is the UTAUT Model in a NonWestern Context?" International Business Research, vol. 8, no. 2, 2015, doi: 10.5539/ibr.v8n2p204.

[17] S. Yaseen and I. El Qirem, "Intention to use e-banking services in the Jordanian commercial banks," International Journal of Bank Marketing, vol. 36, no. 3, pp. 557-571, 2018, doi: 10.1108/ijbm-052017-0082.

[18] M. Tan and T. Teo, "Factors Influencing the Adoption of Internet Banking," Journal of the Association for Information Systems, vol. 1, no. 1, pp. 1-44, 2000, doi: 10.17705/1jais.00005.

[19] J. Thomas and U. Sullivan, "Managing Marketing Communications with Multichannel Customers," Journal of Marketing, vol. 69, no. 4, pp. 239-251, 2005, doi: 10.1509/jmkg.2005.69.4.239.

[20] I. Ajzen, "The theory of planned behavior," Organizational Behavior and Human Decision Processes, vol. 50, no. 2, pp. 179-211, 1991, doi: 10.1016/0749-5978(91)90020-t. 
[21] D. Marafon, K. Basso, L. Espartel, M. de Barcellos, and E. Rech, "Perceived risk and intention to use internet banking," International Journal of Bank Marketing, vol. 36, no. 2, pp. 277-289, 2018, doi: 10.1108/ijbm-11-2016-0166.

[22] Z. Hu, S. Ding, S. Li, L. Chen, and S. Yang, "Adoption Intention of Fintech Services for Bank Users: An Empirical Examination with an Extended Technology Acceptance Model," Symmetry, vol. 11, no. 3, p. 340, 2019, doi: 10.3390/sym11030340.

[23] M. Lee, "Factors influencing the adoption of internet banking: An integration of TAM and TPB with perceived risk and perceived benefit," Electronic Commerce Research and Applications, vol. 8, no. 3, pp. 130-141, 2009, doi: 10.1016/j.elerap.2008.11.006.

[24] T. Kuisma, T. Laukkanen, and M. Hiltunen, "Mapping the reasons for resistance to Internet banking: A means-end approach," International Journal of Information Management, vol. 27, no. 2, pp. 75-85, 2007, doi: 10.1016/j.ijinfomgt.2006.08.006.

[25] V. Nui Polatoglu and S. Ekin, "An empirical investigation of the Turkish consumers' acceptance of Internet banking services," International Journal of Bank Marketing, vol. 19, no. 4, pp. 156-165, 2001, doi: 10.1108/02652320110392527.

[26] S. Chan and M. Lu, "Understanding Internet Banking Adoption and Use Behavior," Journal of Global Information Management, vol. 12, no. 3, pp. 21-43, 2004, doi: 10.4018/jgim.2004070102.

[27] Venkatesh, Morris, Davis and Davis, "User Acceptance of Information Technology: Toward a Unified View," MIS Quarterly, vol. 27, no. 3, pp. 425-478, 2003, doi: 10.2307/30036540.

[28] S. Akter, A.N. Riyadh, and N. Islam, "The adoption of e-banking in developing countries: A theoretical model for SMEs," International Review of Business Research Papers, vol. 5, pp. 212-230, 2009.

[29] A. Yee-Loong Chong, K. Ooi, B. Lin, and B. Tan, "Online banking adoption: an empirical analysis," International Journal of Bank Marketing, vol. 28, no. 4, pp. 267-287, 2010, doi: $10.1108 / 02652321011054963$.

[30] W. Wang and H. Li, "Factors influencing mobile services adoption: a brand-equity perspective," Internet Research, vol. 22, no. 2, pp. 142-179, 2012, doi: 10.1108/10662241211214548.

[31] J. Nunnally and I. Bernstein, Psychometric theory. New Delhi: Tata McGraw-Hill Ed., 2010.

[32] K. Gupta and N. Arora, "Investigating consumer intention to adopt mobile payment systems: an Indian perspective," International Journal of Technology Transfer and Commercialisation, vol. 17, no. 23, pp. 115-134, 2020, doi: 10.1504/ijttc.2020.109388.

[33] M. Farah, M. Hasni, and A. Abbas, "Mobile-banking adoption: empirical evidence from the banking sector in Pakistan," International Journal of Bank Marketing, vol. 36, no. 7, pp. 1386-1413, 2018, doi: 10.1108/ijbm-10-2017-0215.

[34] C. Augusto de Matos, J. Luiz Henrique, and F. de Rosa, "The different roles of switching costs on the satisfaction-loyalty relationship," International Journal of Bank Marketing, vol. 27, no. 7, pp. 506523, 2009, doi: 10.1108/02652320911002331.

[35] A. Zolait, "An examination of the factors influencing Yemeni Bank users' behavioural intention to use Internet banking services," Journal of Financial Services Marketing, vol. 15, no. 1, pp. 76-94, 2010, doi: $10.1057 /$ fsm.2010.1.

[36] L. Pham and D. Anh, "Intention to Use E-Banking in a Newly Emerging Country," International Journal of Enterprise Information Systems, vol. 10, no. 2, pp. 103-120, 2014, doi: 10.4018/ijeis.2014040106. 